\title{
El centelleo de la infamia: los personajes de Historia universal de la infamia
}

\section{Flash of the Infamy: the Characters of $A$ Universal History of Infamy}

\section{Rosario Pérez Bernal}

Facultad de Humanidades, Universidad Autónoma del Estado de México. Ciudad de México, México

amperezb@uaemex.mx

\section{Sonja Stajnfeld}

Facultad de Humanidades, Universidad Nacional Autónoma de México. Ciudad de México, México

sstajnfeld@uaemex.mx

\section{Resumen}

El presente artículo considera las implicaciones proyectadas por los personajes principales de Historia universal de la infamia de Jorge Luis Borges. Los siete protagonistas encarnan un patrón común en su travesía infame: explotan las herramientas del poder empleando palabras -discursos-, según la propuesta de Michel Foucault, a pesar de que estén "al otro lado de la ley". Aunque condicionados por circunstancias histórico-culturales específicas, los héroes-antihéroes comparten la ejecución del mal (para conseguir el goce del poder) y el ascenso al pedestal pseudo-mítico posterior a la cúspide de su infamia. Una de las ideas centrales del artículo es que la tensión entre el mal -abyección- y la ascensión a la categoría del mito -sublimación- origina la descarga de la infamia y configura su imagen universal.

Palabras clave: historia, universalidad, infamia, poder, sublimación, Jorge Luis Borges.

\section{Abstract}

The present article considers the implications projected by the main characters of Universal History of Infamy by Jorge Luis Borges. The seven protagonists embody a common pattern in their infamous trajectory: they exploit the tools of power by using discourse, according to the proposition by Michel Foucault, despite their being "on the other side of the law". Although conditioned by specific historical-cultural circumstances, these heroes-antiheroes share the use of evil (to achieve the pleasure of power) and the ascent to a seudo-mythical pedestal subsequently to the summit of their infamy. One of the central ideas of the article is that the tension between evil -abjection- and the ascension to the category of myth -sublimation- originates the discharge of the infamy and configures its universal image.

Keywords: History, Universality, Infamy, Power, Sublimation, Jorge Luis Borges. 


\section{Introducción a los infames y la infamia}

Infamia, maldad, perversidad, vileza: ¿son universales? ¿Cuál es la causa de la fascinación por los personajes malévolos? A continuación se exponen reflexiones en torno a los infames y la infamia, a partir de los protagonistas de los siete cuentos que forman la primera versión de Historia universal de la infamia ${ }^{1}$ de Jorge Luis Borges, publicada en $1935^{2}$.

Los grandes infames de la historia: Márques de Sade, Gilles de Rais, Atila el Huno (conocido como El azote de Dios), Nerón, Calígula, entre otros, han causado desaprobación; sin embargo, aunado a estos sentimientos de índole negativa, existe fascinación por estos personajes debido a que sus actos perversos traspasaron el umbral de lo que se considera un crimen o una fechoría. Más que un acto transgresor -en el sentido ético- cometido con el fin de obtener un beneficio material, en el caso de estos malhechores, de los infames, su poder supone elevación y sublimación, a través de la cual buscan satisfacción espiritual y/o simbólica.

La publicación de HUI se inscribe en el contexto de la fascinación por los delitos, criminales, gangsters y hechos de sangre cuyo auge en Buenos Aires tuvo lugar en los años veinte y treinta del siglo xx (provocado por el vertiginoso crecimiento urbanopoblacional y territorial, migraciones, proliferación de prensa y nota roja y los cambios sociales consecuentes) ${ }^{3}$. No es soslayable el vínculo de HUI con la escritura de Roberto Arlt, en específico la de temática criminal: tanto con sus aguafuertes, como con las notas periodísticas y los textos literarios ${ }^{4}$. De igual forma, Borges y Arlt encontraban uno de sus principales intereses en individuos que perpetraban crímenes memorables como consecuencia de su maldad. Juárez afirma que:

Es claro, asimismo, el parentesco temático: simuladores e impostores, traidores, gangsters norteamericanos y orientales, asesinos a sangre fría, los infames recorren los textos de Arlt, y sus crónicas también internacionales o universales (en Arlt porque muchos de sus asuntos despuntan del conflicto bélico mundial) aparecen, reiteradamente, cercanas a la biografía: se trata de sucintas y caricaturescas biografías narradas, una vida en pocos trazos (325).

1 Se usará la abreviatura HUI para las referencias a Historia universal de la infamia.

2 Juárez ofrece los siguientes datos: "Es bien sabido que los cuentos que integran Historia universal de la infamia se editan primero en la Revista Multicolor de los Sábados, el suplemento cultural del diario Crítica que dirigían Borges y Ulyses Petit de Murat y que, con ciertas diferencias, aparecen en libro en 1935, en la colección Megáfono (una colección de biografías), de la popularísima editorial Tor, un sello cuyo desprestigio se basaba en la mala calidad de sus ediciones. En 1954, con motivo de sus obras completas, Borges publica nuevamente el libro con algunas variantes" (324).

3 Para más información, ver Olea Franco 78-84 y Juárez 322.

4 Juárez encuentra la razón por la actitud indulgente de Arlt hacia los infames: "es la capacidad de inventiva y la 'perfección geométrica' de la actividad criminal lo que seduce a un cronista bastante complaciente con la picardía y la suspicacia de los estafadores retratados" (328). 
Aunque el interés para tratar a los malvados y los infames en la literatura se halla en ambos escritores, Juárez hace hincapié en la diferencia relativa al asunto del tiempo: "Mientras que en Borges se retrotrae al pasado, y de allí la historia se construye, en Arlt tiene que ver con el registro del presente" (327). Es decir, aunque ambos están envueltos en el ambiente de asombro por los hechos del crimen, el enfoque de Arlt es más bien periodístico, mientras que la aproximación de Borges está en concordancia con sus grandes temas predilectos, como la historia, la universalidad, la eternidad, el tiempo, el azar, la nimiedad del hombre en comparación con estas categorías, entre otros.

En cuanto a la obra de Borges, HUI se inscribe, desde luego, en su dialéctica de la infamia, así como el par de los opuestos, frecuentemente ambiguo en cuanto a sus criterios, del heroísmo-antiheroismo, vinculado con la dicotomía abyecciónsublimación que se desarrolla en el último apartado de este ensayo. Recordemos, por ejemplo, el juego geométrico-espacial y periódico-temporal perfecto en "La muerte y la brújula" para encaminar a Erik Lönnrot al lugar del crimen en el cual será sacrificado por Red Scharlach; la infamia desde la perspectiva de la cobardía y la valentía del Corralero y el Pegador en "Hombre de la esquina rosada"; Judas como el infame arquetípico en "Tres versiones de Judas"; Loewenthal que induce al padre de Emma Zunz al suicidio y a ella a vengarlo; el nazi Otto zur Linde, subdirector del campo de concentración responsable de la tortura del poeta David Jerusalem en "Deutches Requiem"; el incomprendido Asterión precisamente en "La casa de Asterión". La enumeración podría seguir encadenándose; sin embargo, en este ensayo nos ceñimos a los infames de HUI puesto que su caracterización representa, según Valderrama, "una separación entre dos épicas" (117), específicamente, entre la que enfatiza la figura del gaucho y su importancia en la tradición argentina, por un lado, y la "que incluye al personaje como herramienta de la búsqueda ulterior de la identidad individual" (117), por otro; es decir, la publicación de HUI representa el punto de inflexión entre las dos tendencias estéticas de Borges.

Se procederá con una visión abarcadora de los siete protagonistas de HUI con el fin de, a través de denominadores comunes, obtener explicación sobre el fenómeno de la infamia en el sentido abstracto. Por consiguiente, nos concentraremos en cómo identidades tan dispersas -cultural y temporalmente- proyectan una idea íntegra de la infamia. Específicamente, el enfoque se dará en la tradición a la que se adscribe cada infame -condicionada por los referentes arquetípicos, culturales y temporales-y en las relaciones de poder que los infames efectúan para consolidarse como líderes. Asimismo, para adentrarse en su surgimiento, apogeo y ocaso, hay que entender la dinámica, la coexistencia y la tensión entre la sublimación y la abyección, ${ }^{5}$ ambas presentes en los siete protagonistas de HUI. Los actos abyectos son obvios: se trata, a

5 Nociones contradictorias que Élisabeth Roudinesco contempla como componentes constitutivos de la perversión. En adelante, nos detendremos más meticulosamente en esta propuesta. 
grandes rasgos, de engaños, asesinatos, robos, torturas, humillaciones, etc. ${ }^{6}$ En cuanto a la sublimación, esta se halla en la calidad del héroe malvado, o sea, en su reconocimiento como tal por los otros, ya sean seguidores o adversarios.

\section{Culturas e identidades versus historia y universalidad}

El conjunto de cuentos con protagonistas infames titulado HUI contiene, desde el título, tres nociones abstractas: historia, universalidad e infamia. No se trata de historias sino de historia en singular, una historia reforzada, por si fuera poco, con la palabra universal, la cual remite a los siguientes valores definidos por el Diccionario de la Real Academia Española: "que comprende o es común a todos en su especie, sin excepción de ninguno", "que lo comprende todo en la especie de que se habla", "que pertenece o se extiende a todo el mundo, a todos los países, a todos los tiempos". En otras palabras, los siete cuentos reunidos bajo este título pretenden presentar una imagen íntegra, absoluta y completa de la infamia -el mal- encarnada por ciertos personajes. Desde luego, lo universal anunciado se anula en el contacto con cada texto, ya que sus epifanías concretas, referidas a siete personajes ubicados espacial y temporalmente, además de condicionados culturalmente, parecen contraponerse a la tendencia totalizadora.

Entre el título globalizador y los protagonistas acentuadamente definidos por sus referentes culturales, pulula la tensión intrínseca entre las partes -culturas, según la acepción de "conjunto de modos de vida y costumbres, conocimientos y grado de desarrollo artístico, científico, industrial, en una época, grupo social, etc.” (DRAE)- y el todo: historia y universalidad. Debido a que el título engloba las siete muestras -partes-, nos inclinamos por la interpretación integradora, sin desestimar la importancia de los escenarios culturales de cada texto. Otro motivo de nuestro enfoque es la siguiente sentencia del cuento "El asesino desinteresado Bill Harrigan": "La Historia (que, a semejanza de cierto director cinematográfico, procede por imágenes discontinuas) propone ahora la de una arriesgada taberna, que está en el todopoderoso desierto igual que en alta mar" (64). Esta reflexión del autor afirma la naturaleza manipuladora de la Historia, ya que es de acuerdo con su voluntad que algunos personajes, escenarios y periodos (y los detalles que los acompañan) son seleccionados para el desenvolvimiento de los eventos fatídicos.

6 Aunque no es el propósito de este ensayo, que se centra en la imagen proyectada por los infames y no en las causas de su condición, brevemente se hará eco en la teoría psicoanalista, la cual constituye uno de los grandes discursos del poder del siglo xx. Por supuesto que, en este contexto, la causa de la infamia -manifiesta en los actos de violencia y perversidad- se halla en el inconsciente, en este depósito de los deseos reprimidos, así como en sentimientos, memorias, impulsos instintivos que no encontraron satisfacción; por consiguiente, pasan por los procesos de traducción y acaban en síntomas neuróticos, es decir, la expresión indirecta que permite la liberación de la energía impulsiva inaceptable socialmente. Para más información, ver Rivkin y Ryan 389-96. 
Resumiendo el punto anterior, la intención de HUI opera sobre dos principios: primero, proponer la universalidad (espacial y temporal) de la infamia, es decir, de sus manifestaciones concretas de avaricia, engaño, manipulación, impostura, crueldad, venganza, traición, lujuria, soberbia, saqueo, entre otras; y segundo, proponer la universalidad (espacial y temporal) de los héroes infames, su creación a través de los medios de poder -en especial los que tienden a ser represores- y su ascensión al pedestal de los héroes.

Los protagonistas demuestran una diversa gama cultural que se refleja, entre varias referencias, en su pertenencia a determinados contextos histórico-culturales. Lazarus Morell habita en el sur estadounidense, dentro del contexto histórico del amanecer de la conciencia de la liberación de los esclavos; Tom Castro es originario de la Inglaterra del siglo xix pero, respondiendo al llamado "Run away to sea" (32), conoce las tierras sudamericanas, así como Australia (lo anterior, se pudiera suponer, le otorgaba un amplio conocimiento geográfico y cultural, aunque nunca le ayudó a conquistar el ingenio); la viuda Ching "operó en las aguas del Asia, desde el Mar Amarillo hasta los ríos de la frontera del Annam” (42), entre los siglos XVIII y xIX; el gánster Monk Eastman vivió también en los Estados Unidos, pero en la turbulenta sociedad neoyorkina de las bandas enemigas de finales del siglo xıx e inicios del xx; Billy the Kid, en el ambiente de la fiebre amarilla estadounidense y la consecuente migración al Oeste, hacia el territorio inflamable de la frontera con México; Kotsuké no Suké pertenece al mundo de los samuráis, con reglas estrictas y sanciones irreversibles por su incumplimiento; finalmente, Hákim de Merv, el Profeta Velado, pertenece a la cultura islámica y de Asia Central en el siglo viII, "[a] los 120 años de la Hégira y 736 de la Cruz" (80). Teniendo en cuenta que las tradiciones suponen normas y costumbres conservadas y transmitidas por un grupo social, veremos en adelante que estas son -según los principios de Michael Foucault que se explicarán luego- herramientas usadas por los sistemas de poder que este autor califica como represivos.

\section{Manipulación de la Historia}

El doble sentido del presente subtítulo refleja la idea de los textos sobre la infamia. Por un lado, se permite la lectura de la Historia en su calidad de agente o sujeto, de una Historia activa y sobre todo manipuladora. Por otro lado, la Historia es pasiva, es la que sufre manipulación por parte de los ejes de poder que exigen la presencia de los infames en la sociedad. Es llamativo que unas circunstancias y episodios históricos azarosos (concepto controvertido, refiriéndose a los textos de Borges) creen a los héroes infames; es decir, los héroes son más bien eslabones en la tradición del mal condicionada espacial y temporalmente. Esta es posiblemente una de las razones de la aseveración de Borges, en el prólogo a la edición de 1954, sobre la superficialidad del mal y del malvado: "Patíbulos y piratas lo pueblan [este libro] y la palabra infamia 
aturde en el título, pero bajo los tumultos no hay nada. No es otra cosa que apariencia, que una superficie de imágenes" (10-11); esto se halla implícito en HUI: el mal como categoría relativa. Lo sublime, lo trascendente, es, según el autor, una apariencia: desde la perspectiva de algo tan inmenso como la historia universal, los rasgos distintivos, las identidades particulares y las modalidades de ejecución de los hechos infames, así como las transgresiones de las normas y los valores específicos -verdad, respeto, integridad corporal, libertad, propiedad, vida, humildad, dignidad-se homogenizan para confirmar una historia universal de la infamia. Otra vez regresamos a la idea de una Historia manipuladora: los infames que lograron transcender, provocar un eco, son unas especies de títeres manipulados por las circunstancias históricas. A continuación, veremos los ejemplos de lo anterior, considerando las características de cada personaje.

El infame que abre HUI es Lazarus Morell, quien "[mantenía] en su postración un orgullo: el de la sangre sin un tizne, sin mezcla” (21). El discurso racial concentrado en la cita tiene su origen en la evocación del Padre Bartolomé de la Casas: "En 1517 el P. Bartolomé de las Casas tuvo mucha lástima de los indios que se extenuaban en los laboriosos infiernos de las minas de oro antillanas, y propuso al emperador Carlos v la importación de negros que se extenuaran en los laboriosos infiernos de las minas de oro antillanas" (17). Esta propuesta encadenó un sinfín de eventos y cambios culturales, sociales, económicos, jurídicos, etcétera, que resultaron del contacto de la raza negra con las de otras latitudes. Se inician los sucesos vinculados con la presencia de la raza negra, desde los hechos sanguíneos hasta el surgimiento de corrientes musicales diferentes, pasando por nuevos valores lingüísticos. Uno de los diversos frutos de esta propuesta del padre Bartolomé, aceptada por el emperador, es el "atroz redentor" (17) Lazarus Morell. Además de las causas históricas, que son más indirectas, este falso liberador de los esclavos fue el resultado del ambiente inmediato y de la segregación formal de la población estadounidense de acuerdo con el parámetro racial. Según aquella, él pertenece a "los poor whites, la canalla blanca. Eran pescadores, vagos cazadores, cuatreros. De los negros solían mendigar pedazos de comida robada y mantenían en su postración un orgullo: el de la sangre sin un tizne, sin mezcla" (21). Su aspiración era, después de que lo traicionara uno de los suyos, "una sublevación total de los negros, la toma y el saqueo de Nueva Orleans y la ocupación de su territorio" (27). La construcción espiral que desembocó en el personaje Lazarus Morell demuestra que la infamia empezó con el Padre Bartolomé de la Casas y que el atroz redentor es el último eslabón hasta el momento de dicha narración. De acuerdo con František Vrhel:

Desde el punto de vista de la verosimilitud del relato, Morell es, efectivamente, un redentor. Desde el punto de vista que rompe el verosímil, Morell es atroz. Esto explica, entonces, el título oximorónico del cuento [...] A la luz de esta imagen doble, la mención del famoso defensor de los indios Bartolomé de Las Casas adquiere una connotación maliciosa, porque también Las Casas de repente aparece como "un redentor atroz" (26). 
Según la propuesta de este autor, la Historia es pasiva; otra manera de verlo, más congruente, creemos, con la visión de Borges, es que la Historia urdió las circunstancias para la importación de negros a través de Bartolomé de la Casas; podría decirse que la Historia posee una especie de voluntad propia, asemejándose al director de una obra teatral.

La descendencia infame de Tom Castro es menos colosal que la de Lazarus Morell. Antes de sucumbir a la convocación del instinto infame, se entrega a la tradición del "llamado del mar" (31) como muchos de sus compatriotas en aquella época. La infamia, sin embargo, no emana de él, sino de su doble, Bogle: "En Castro, la 'infamia’ es tanto la maquinación de Bogle como la de los parientes de Lady Tichborne" (Barros-Lémez). Esta amistad o, en las palabras de Borges, "protectorado" (33), ha estado compuesta por el "negro inseguro y monumental" y "el obeso tarambana de Wapping" (33). Otro contraste de la caracterización en que se insiste, aparte del aspecto físico, es la ingeniosidad de Bogle versus la sandez de Tom Castro; Borges describe a Castro así: "Era persona de una sosegada idiotez. Lógicamente, hubiera podido (y debido) morirse de hambre, pero su confusa jovialidad, su permanente sonrisa y su mansedumbre infinita le conciliaron el favor de cierta familia de Castro" (32). Bogle, en cambio, "sin ser hermoso, tenía ese aire reposado y monumental, esa solidez como de obra de ingeniería que tiene el hombre negro entrado en años, en carnes y en autoridad. Tenía una segunda condición, que determinados manuales de etnografía han negado a su raza: la ocurrencia genial" (32). En cuanto a las circunstancias que posibilitaron dicha alianza entre un blanco absurdo y un negro solemne, no existía otra salvo la moda del llamado del mar.

La viuda Ching suntuosamente representa la tradición femenina de piratas o corsarias: "mujeres hábiles de la maniobra marinera, en el gobierno de tripulaciones bestiales y en la persecución y saqueo de naves de alto bordo" (41). Es sucesora de las grandes piratas como Mary Read, según la cual "la profesión de pirata no era para cualquiera [...], era preciso ser un hombre de coraje como ella" (41). Otro factor a considerar es el modelo de los piratas en general, independientemente del sexo, así como el contexto histórico-cultural chino, del cual surgen la disciplina y los castigos extremos (de ahí el reglamento redactado por la viuda, que establecía la muerte como castigo en caso de incumplimiento). El desenlace de la historia de la única mujer infame de HUI está inserto en la cosmovisión oriental, primero con la mención de la fábula del dragón y la zorra, y posteriormente con la conversión de su nombre en Brillo de la Verdadera Instrucción.

"El proveedor de iniquidades Monk Eastman" inicia con una muestra de la violencia elegante, refiriéndose a la cultura latinoamericana. Es una violencia con pundonor, reglas, estilo, puntillo, caballerosidad: "un baile gravísimo, que es el de los cuchillos parejos" (51). Es decir, si el narrador se refiere a la primera significación de "bailar": "ejecutar movimientos acompasados con el cuerpo, brazos y pies" (DRAE, la cursiva es nuestra), se trata de un movimiento con ritmo y con cierta violencia 
dominada por los preceptos del decoro. La escena del duelo al estilo latinoamericano funciona como introducción y contrapunto para la historia de la violencia norteamericana que es central en la narración. Además de servir para establecer la discrepancia entre ambas culturas, la escena es útil para introducir la violencia como tema principal y presentarla como el denominador común de las (dos) culturas. La importancia de adscribirse a cierta tradición y grupo se percibe en la enumeración de las bandas de Nueva York en el amanecer del siglo xx; estas se caracterizan por "la confusión y la crueldad de las cosmogonías bárbaras y mucho de su ineptitud gigantesca" (52). Los nombres de las bandas concuerdan con su oficio: Ángeles del Pantano, Muchachos del Alba, Galerudos Fieros, Conejos Muertos; los nombres y los alias del héroe, Edward Ostermann de nacimiento, se afilian también a esta costumbre: "Edward Delaney, alias William Delaney, alias Joseph Marvin, alias Joseph Morris, alias Monk Eastman" (53) ${ }^{7}$.

El modelo de "El asesino desinteresado Bill Harrigan" es el de "un jinete clavado sobre el caballo" (61). Este infame es uno de los representantes de los cowboys, que conoció en las ficciones teatrales que frecuentaba de niño: "le gustaba asistir (acaso sin ningún presentimiento de que eran símbolos y letras de su destino) a los melodramas de cowboys" (63). Personificando el modelo del jinete, frecuenta las tabernas de esa zona difusa de la frontera Estados Unidos-México, holgadamente ubicada en "las tierras de Arizona y de Nuevo Méjico, tierras con un ilustre fundamento de oro y plata, tierras vertiginosas y aéreas, tierras de la meseta monumental y de los delicados colores, tierras con blanco resplandor de esqueleto pelado por los pájaros" (61).

El incivil maestro de ceremonias Kotsuké no Suké perpetúa la tradición nutrida por "dos mil trescientos años de cortesía (algunos mitológicos)"; su función como maestro de ceremonias era la de preparar la llegada del enviado imperial quien "representaba al emperador, pero a manera de alusión o de símbolo" (70). El infame maestro transgredió su encargo humillando a su anfitrión. Por lo anterior, sufrió venganza, pero la recibió como un infame sin dignidad, rechazando suicidarse.

Como se ha dicho, "El tintorero enmascarado Hákim de Merv" se relaciona con la cultura del Islam. El profeta Hákim se presenta ciento veinte años después de la fundación de la tercera religión abrahámica monoteísta. Una lectura atenta a las referencias culturales revela su calidad de impostor desde la enumeración de "las fuentes originales" (79) sobre Al Moqanna: Historia de los jalifas, un libro

7 Sumado a esto, transcribimos un fragmento del libro Las letras de Borges de Sylvia Molloy, quien reflexiona sobre las identidades confusas y desplazamientos de los infames: "Así, Arthur Orton será sucesivamente Tom Castro y Roger Charles Tichborne; Bill Harrigan pasará a ser Billy the Kid; la viuda Ching se trasmutará en Brillo de la Verdadera Instrucción; Edward Osterman será Monk Eastman pero también Edward Delaney, 'alias William Delaney, alias Joseph Marvin, alias Joseph Morris, alias Monk Eastman', con lo cual el propio nombre que será posteriormente dado como verdadero y nacido de la 'americanización' de un apellido originalmente europeo, queda también en cuestión; Hákim de Merv será Al Moqanna, 'el Profeta Velado, el 'Enmascarado, 'El Velado' o utilizará la cabeza de toro como máscara visible. Morell y el vengador de Asano Takumi no Kami -el consejero Kuranosuké- se 'enmascara' a través de sus acciones y su ubicuidad, aunque el primero morirá como Silas Buckiey en el hospital de Natchez" (39). 
escrito por el "historiador oficial de los Abbasidas" (79), un códice árabe y unas monedas sin efigie $e^{8}$, ninguna de las cuales es una fuente reconocida por el Islam como reveladora 9 .

Otras remisiones culturales son los escenarios del cuento: Turquestán, región de Asia Central; el desierto; Jorasán, actualmente región cuya mayor parte está en Afganistán, pero también se extiende en Irán y Turkmenistán; la ciudad de Nishapur de Jorasán; Astarabad, actualmente conocido como Gorgan. El Islam se expandió en esas tierras en el periodo conocido como el de los Jalifas Ortodoxos, los cuatro jalifas que sucedieron a Mahoma.

En cuanto al modelo, Hákim se adscribe al de los profetas. Su personificación de profeta inicia con una travesía para difundir su dogma; asimismo, narra la conversión de tintorero a profeta: "Así pequé en los años de juventud y trastorné los verdaderos colores de las criaturas. El Ángel me decía que los carneros no eran del color de los tigres, el Satán me decía que el Poderoso quería que lo fueran y se valía de mi astucia y mi púrpura. Ahora yo sé que el Ángel y el Satán erraban la verdad y que todo color es aborrecible" (81). Otro episodio en su conformación como profeta es la experiencia cercana con lo divino:

el año 146 de la Emigración había penetrado un hombre en su casa y luego de purificarse y rezar le había cortado la cabeza con un alfanje y la había llevado hasta el cielo. Sobre la derecha mano del hombre (que era el ángel Gabriel) su cabeza había estado ante el Señor, que le dio misión de profetizar y le inculcó palabras tan antiguas que su repetición quemaba las bocas y le infundió un glorioso resplandor que los ojos mortales no toleraban (83).

Con lo anterior, Hákim justifica su máscara, pero también su condición de iluminado, profeta, y el hecho de que sus acompañantes sean ciegos. Congruentemente con la tradición profética, el impostor Hákim se enfrenta con la incredulidad de la gente y demuestra, con una prueba, que es el profeta:

Alguien había traído un leopardo -tal vez un ejemplar de esa raza esbelta y sangrienta que los monteros persas educan. Lo cierto es que rompió su prisión. Salvo el profeta enmascarado y los dos acólitos, la gente se atropelló para huir. Cuando volvieron, había enceguecido la fiera. Ante los ojos luminosos y muertos, los hombres adoraron a Hákim y confesaron su virtud sobrenatural (83).

El acto de enceguecer al animal era suficiente para congregar a los fieles. El método para lograrlo se podría hallar en el hecho que Hákim de Merv ajusta "la ideología compartida por una sociedad [...] a sus necesidades para manipular colectivos, [lo que crea] un estado de libertad que, dadas sus circunstancias, no [habría] podido

8 Las monedas sin efigie alimentan el mito de Al Moqanna, llamado también el Profeta Velado.

9 El Islam reconoce cuatro fuentes: el Corán, la Torá, los Salmos y el Evangelio. 
disfrutar" (Valderrama 98). En otras palabras, sin que las circunstancias históricas se conjugaran de manera específica para que favorecieran la necesidad del surgimiento del profeta, él no hubiera podido acceder a la infamia ni, más tarde, a la fama.

Independientemente de si la Historia es el director o el actor de la obra que impone o no su voluntad, en este apartado hemos observado que los infames se inscriben en contextos histórico-culturales específicos y perpetúan sus acervos de normas y costumbres, adscribiéndose así a los modelos de diversos grupos, oficios o representaciones.

\section{El poder de la infamia}

La fascinación universal por los héroes infames es un fenómeno llamativo debido, entre otras razones, a la imposibilidad de llegar a una conclusión tajante: ¿esta fascinación hace al héroe infame (alimentando y exagerando su "historia" para crear un mito) o este se hace, se erige por sus propias fuerzas? En su libro La vida de los hombres infames, Michel Foucault argumenta ampliamente a favor de la primera conjetura; según este pensador, el poder siempre necesita de los otros (los infames, en este caso), seleccionados al azar, para consolidarse:

Ha sido el azar quien ha hecho que la vigilancia de los responsables o de las instituciones, destinadas sin duda a borrar todo desorden, prefiriesen a un sujeto en vez de a otro, a ese monje escandaloso, a esa mujer golpeada, a ese borracho inveterado y furioso, a ese comerciante que no cesa de querellarse, en lugar de a tantos otros que a su lado no han producido menos alborotos (184).

El filósofo e historiador asevera que el contacto con el poder lanza a los otros del anonimato a la fama: "Una luz que les venía de fuera: lo que las arrancó de la noche en la que habrían podido, y quizás debido, permanecer fue su encuentro con el poder; sin este choque ninguna palabra sin duda habría permanecido para recordarnos su fugaz trayectoria" (181). Retomando la idea de la manipulación de la historia, Foucault se inclina hacia la idea de la responsabilidad de las fuerzas incomprensibles, como el azar, el destino, la historia, en la "elección" de los infames potenciales, aunque, una vez elegidos, otras fuerzas -las del poder y de la necesidad del otro, el infame- adquieren protagonismo.

En la introducción a Yo, Pierre Rivière, habiendo degollado a mi madre, mi hermana y mi hermano..., Angelo Morino resume la dinámica de la necesidad del infame para el Estado y la justicia:

No bien se ha producido el hecho-infracción, se cristalizan en torno a él los signos de una institución cuyo deber es castigar aquello que constituye una violación a la norma. El introducir este hecho en el patrimonio de la memoria colectiva se justifica así por la funcionalidad de la praxis de una jerarquía que garantiza la tutela de ciertos valores y sanciona el castigo del que los transgrede (III). 
Otro punto a considerar es que, de acuerdo con Foucault, el arma del poder para exponer al infame, construirlo como tal y, al mismo tiempo, consolidarse es la palabra, el discurso: "las pobres almas perdidas por caminos ignotos, todos ellos son infames en pleno derecho ya que existen gracias exclusivamente a las concisas y terribles palabras que estaban destinadas a convertirlos para siempre en seres indignos de la memoria de los hombres" (185). Esta arma puede asumir las formas del informe policial, el informe forense, el testimonio, la evaluación médica, el reglamento, la lettre de cachet, las leyes, entre muchas otras: "Se utilizan de forma sistemática [...] procedimientos antiguos hasta entonces muy locales: la denuncia, la querella, la encuesta, la delación, el interrogatorio" (189). En cuanto a los constituyentes del poder que emplean el arma de la palabra, Foucault comenta que, por más que se dediquen a asuntos aparentemente diferentes, su objetivo es el mismo: "todos ellos, y dentro de su heterogeneidad, no forman ni una obra ni un texto, sino una singular querella, un enfrentamiento, una relación de poder, una batalla de discursos y a través de los discursos" (Rivière 10). De los personajes que nos interesan en este ensayo, los casos más evidentes en este sentido son Lazarus Morell y Hákim de Merv, quienes, a través del poder de sus discursos -específicamente, la manipulación de los sentimientos por medio de la palabra-, son capaces de formar un ejército de seguidores.

Las relaciones de poder - una de las constantes preocupaciones foucaltianas- se podrían pensar, en el caso de los infames de HUI, como relaciones con el poder, como un intercambio y una retroalimentación entre el poder institucional y el poder de la infamia, específicamente, del héroe infame. Argüiríamos que los dos lados opuestos de la ley acceden al poder utilizando mecanismos represivos de forma alterna: en la cúspide del poder del infame, el poder institucional está ausente o suprimido y viceversa. Foucault hace una pregunta retórica: “ ¿No constituye uno de los rasgos fundamentales de nuestra sociedad el hecho de que el destino adquiera la forma de relación al poder, de la lucha con o contra él?"; y luego comenta: "El punto más intenso de estas vidas [de los infames], aquel en que se concentra su energía, radica precisamente allí donde colisionan con el poder, luchan con él, intentan utilizar sus fuerzas o escapar a sus trampas" (182). Los siete infames que abordamos luchan contra el poder desafiando y transgrediendo sus leyes, regulaciones y valores, y al mismo tiempo utilizan los mecanismos de este poder para fortalecer su discurso, verdad y liderazgo. En su calidad de líderes, los infames establecen sus propios sistemas represivos de control.

En el caso de Lazarus Morell, se trata del "método" establecido por él, que es "único, no solamente por las circunstancias sui generis que lo determinaron, sino por la abyección que requiere, por su fatal manejo de esperanza y por el desarrollo gradual, semejante a la atroz evolución de una pesadilla" (23). El reglamento se percibe en lo siguiente:

En cuanto a cifras de hombres, Morell llegó a comandar unos mil, todos juramentados. Doscientos integraban el Consejo Alto, y éste promulgaba las órdenes 
que los restantes ochocientos cumplían. El riesgo recaía los subalternos. En caso de rebelión, eran entregados a la justicia o arrojados al río correntoso de aguas pesadas, con una segura piedra a los pies (23).

No obstante, su organización jerarquizada no logra impedir la traición de Virgil Stewart quien "rompió su juramento y delató a Morell y a los otros" (26).

La condición de la infamia del inverosímil impostor Tom Castro es dudosa o, mejor dicho, delegada a su doble, Bogle, quien es realmente el tejedor de la impostura. Aunque no se declara explícitamente, el sistema o el método de Bogle, quien es iluminado por la inspiración divina, consiste en provocar y alimentar la duda en su propia invención de impostura, con el fin de demostrar que los que ponen en tela de juicio la autenticidad de Tichborne son tendenciosos, con intereses egocéntricos: “Su efecto fue inmediato: las buenas gentes no dejaron de adivinar que Sir Roger Charles era blanco de un complot abominable de los jesuitas" (38).

El código impuesto por la viuda Ching es el más axiomático: "El reglamento, redactado por la viuda Ching en persona, es de una inapelable severidad, y su estilo justo y lacónico prescinde de las desfallecidas flores retóricas que prestan una majestad más bien irrisoria a la manera china oficial" (44). A manera de ejemplo, transcribimos los artículos seleccionados:

Todos los bienes transbordados de naves enemigas pasarán a un depósito y serán allí registrados. Una quinta parte de lo aportado por cada pirata le será entregada después; el resto quedará en el depósito. La violación de esta ordenanza es la muerte.

La pena del pirata que hubiere abandonado su puesto sin permiso especial será la perforación pública de sus orejas. La reincidencia de esta falta es la muerte.

El comercio con las mujeres arrebatadas en las aldeas queda prohibido sobre cubierta; deberá limitarse a la bodega y nunca sin el permiso del sobrecargo. La violación de esta ordenanza es la muerte (45).

También la alimentación a bordo es controlada con la imposición de una disciplina estricta: "informes suministrados por prisioneros aseguran que el rancho de esos piratas consistía principalmente en galleta, en obesas ratas cebadas y arroz cocido" (45).

El poder oficial, representado por el joven emperador Kia-King, sitúa a la viuda y sus piratas fuera de la ley mediante el siguiente discurso:

Hombres desventurados y dañinos, hombres que pisan el pan, hombres que desatienden el clamor de los cobradores de impuestos, hombres que dejan que sus lágrimas corran mirando el Norte, molestan la ventura de nuestros ríos y la antigua confianza de nuestros mares. [...] Violan así las leyes naturales del Universo, de suerte que los ríos se desbordan, las riberas se anegan, los hijos se vuelven contra los padres y los principios de humedad y sequía son altera$\operatorname{dos} \ldots(46-7)$. 
Finalmente, es el poder imperial el que vence a la infame viuda y ella se dedica a un oficio "legal", el contrabando de opio (la ironía es evidente). Lo conspicuo aquí es que en la cúspide de su poder, la viuda ejecutaba mecanismos regulatorios análogamente a una instancia del poder oficial.

Billy the Kid erige su personalidad a través de reglas firmes no escritas, en cuyo centro está la figura del jinete. Después del asesinato del mexicano Belisario Villagrán quien desafió a los “auténticos" gringos - "En duro inglés desea las buenas noches a todos los gringos hijos de perra que están bebiendo" (65)-, Bill se gana el respeto primero entre los asistentes de aquella taberna - "De esa feliz denotación (a los catorce años de edad) nació Billy the Kid el Héroe y murió el furtivo Bill Harrigan" (66)- y luego teje, paulatinamente, el mito de su personaje: "Nunca se pareció del todo a su leyenda, pero se fue acercando" (66). Con ese asesinato, Bill Harrigan obtiene admiradores y se convierte en un líder que debe suscribir un código de conducta que le ordena, por ejemplo, grabar una marca en el revólver por cada asesinado.

"El proveedor de iniquidades Monk Eastman" se ha iniciado con el contraste de la violencia del estilo latinoamericano versus norteamericano; como hemos dicho, la historia de Monk Eastman pertenece a la violencia de América del Norte, caracterizada por ser salvaje y sin reglas (contrariamente a la de América Latina). Monk asume su posición de líder mediante asesinatos brutales, ganándose un lugar con la denominada "ley de la selva". Como otros héroes infames, él también impone mecanismos de control; a diferencia de ellos, está directamente coludido con el poder del lado oficial de la ley:

Desde 1899 Eastman no era sólo famoso. Era caudillo electoral de una zona importante, y cobraba fuertes subsidios de las casas de farol colorado, de los garitos, de las pindongas callejeras y los ladrones de ese sórdido feudo. Los comités lo consultaban para organizar fechorías y los particulares también. He aquí sus honorarios: 15 dólares una oreja arrancada, 19 una pierna rota, 25 un balazo en la pierna, 25 una puñalada, 100 el negocio entero (56).

Monk Eastman, de las pandillas de Nueva York -del otro lado de la ley-, asciende a la legitimidad alistándose en un regimiento de infantería para luchar contra Alemania en la Primera Guerra Mundial, en una guerra "justa", "legítima” y "heroica”, de acuerdo al discurso oficial.

En relación con las herramientas de control de la estrictamente regulada civilización japonesa, el cuento del infame maestro de ceremonias testimonia normas que rigen ese mundo. El agredido Takumi no Kami es inducido al suicidio debido a la herida que ha infringido al incivil maestro. Lo anterior es una injusticia, ya que el señor de la Torre de Ako sufrió una humillación por parte del infame Kotsuké no Suké, y su acto agresivo fue la pérdida de control frente al ultraje; ejecutó su propia justicia en un estado de perturbación. Esto suscita, de acuerdo con el código de esa cultura, la venganza de los cuarenta y siete capitanes (fieles al señor) contra el infame. 
La muerte de estos hombres leales es regularizada también: "La Suprema Corte emite su fallo. Es el que esperan: se les otorga el privilegio de suicidarse" (76). La infamia de Kotsuké no Suké, aparte de humillar a su anfitrión, es la de burlar la posición de samurái rechazando suicidarse, por lo que transgrede otra norma: "En vano propusieron ese decoro a su ánimo servil. Era varón inaccesible al honor; a la madrugada tuvieron que degollarlo" (75).

Kotsuké no Suké pertenece al orden oficial representando por el emperador; transgrede, sin embargo, las normas del respeto y la dignidad, lo que lo convierte en infame. Su mérito, como dice Borges, es el de personificar el contrapunto necesario para la cohesión social: "Es hombre que merece la gratitud de todos los hombres, porque despertó preciosas lealtades y fue la negra y necesaria ocasión de una empresa inmortal” (69).

En el caso del Profeta Al Moqanna, las pautas para confirmarse como profeta funcionan como normas regulatorias: la conversión, la prueba, la congregación de adeptos. Aparte de estos "pasos" que forman un sistema regulatorio, también encontramos, por ejemplo, el de diferenciarse de Banú Abbás ${ }^{10}$ para sustituirlo en el poder: "Hákim, ya entonces, descartó su efigie brutal por un cuádruple velo de seda blanca recamado de piedras. El color emblemático de los Banú Abbas era el negro; Hákim eligió el color blanco -el más contradictorio- para el Velo Resguardador, los pendones y los turbantes" (84). El enfrentamiento con el poder, encarnado por el jalifa Mohamed Al Mahdí, lo obliga a institucionalizar su religión, "si bien con evidentes infiltraciones de las prehistorias gnósticas" (85).

El enfrentamiento con el jalifa hace que Hákim defina su doctrina: "En el principio de [su] cosmogonía hay un Dios espectral [que] carece majestuosamente de origen, así como de nombre y de cara" (85-6). Establece, entre otros preceptos, que "la tierra que habitamos es [...] una incompetente parodia", que "el asco es la virtud fundamental" y que "dos disciplinas (cuya elección dejaba libre el profeta) pueden conducirnos a ella [la virtud]: la abstinencia y el desenfreno, el ejercicio de la carne o su castidad” (86). La religión de Hákim contempla la existencia tanto del paraíso como del infierno: el infierno es "maravilloso" (86), con una forma espiral de 999 fuegos, mientras que el paraíso "es menos concreto. Siempre es de noche y hay piletas de piedra, y la felicidad de ese paraíso es la felicidad peculiar de las despedidas, de la renunciación y de los que saben que duermen" (87).

Los siete protagonistas infames de Borges emplean mecanismos represivos para ascender y consolidarse en el poder. El poder oficial, por su parte, persigue, abate, a los infames con las herramientas clásicas de control y disciplina. Aunque Lazarus Morell logra escapar, su casa "fue cercada por la justicia" (26); Tom Castro "fue condenado a catorce años de trabajos forzados" (40); la viuda Ching se somete al poder del emperador pidiendo su perdón: "La zorra busca el ala del dragón” (50); Monk Eastman

10 Tío de Mahoma; sus descendientes establecieron el califato abásida. 
"fue arrestado, por enésima vez. [...] el juez le vaticinó, con toda verdad, diez años de cárcel” (59); el comisario Garrett, el sheriff, mata a Billy the Kid "[descerrajándole] un balazo en el vientre" (67); los vengadores del señor de la Torre ejecutan la justicia sobre el infame Kotsuké no Suké: "a la madrugada tuvieron que degollarlo" (75); el profeta impostor Hákim es linchado por sus exadeptos: "lo atravesaron con lanzas" (88). Resumiendo, la única manera de ascender al pedestal de líder o alimentar la leyenda del héroe, aunque esté del otro lado de la ley (antihéroe), es hacer cumplir los fundamentos universales de poder, principalmente a través de la palabra y el discurso, para posteriormente infligir violencia y tortura.

\section{Los héroes infames, entre abyección y sublimación}

Si bien los famosos infames (valga la aliteración) son seres seleccionados por las circunstancias o "el Destino", según Borges - "tal es el nombre que aplicamos a la infinita operación incesante de millares de causas entreveradas" (37)-, estos personajes lograron, por paradójico que suene, una efímera transcendencia, gloria y cierta sublimación causada, intentaremos argumentar, por sus actos abyectos. El propio Borges lo insinúa en el prólogo a la primera edición de HUI: "[Los ejercicios de prosa narrativa que integran este libro abusan] de algunos procedimientos: [...] la reducción de la vida entera de un hombre a dos o tres escenas" (7). Nos hemos referido a los protagonistas como héroes infames, ya que, oscilando en la dicotomía sublime-abyecto, adquieren características míticas y épicas. Marta Gallo, analizando los aspectos épicos de HUI, traza la analogía entre los infames y los héroes épicos:

La narración llama héroes explícitamente a varios personajes de HUI [...] y les atribuye el aura típica de un héroe, la fama, aunque las hazañas que la confieren no sean sino "famosas infamias" como la de Kotsuké no Suké [...]: muertes, robos, engaños, crueldades. Estos héroes modernos, al quebrarse la armonía con su mundo, encarnan aun en sus res gestae (como en la epopeya tradicional) los mismos valores de su entorno, pero ahora en función personal y ya no de la comunidad, con la que antagonizan (95-6).

La coexistencia de estos dos extremos en la caracterización de los protagonistas nos ha sugerido la imagen de Jano, con una cara sublime y otra abyecta. En esta dicotomía y coexistencia de las calidades antagónicas se encuentra, según Élisabeth Roudinesco, la explicación de la fascinación implícita en la perversión ${ }^{11}$ :

La fascinación que ejerce sobre nosotros la perversión tiene que ver precisamente con el hecho de que puede ser tanto sublime como abyecta. Sublime cuando se

11 Aunque el interés de Roudinesco se centra específicamente en los perversos y la perversión, reconocemos numerosos aspectos en común con los infames y la infamia concebidos por Borges. 
manifiesta en rebeldes de carácter prometeico, que se niegan a someterse a la ley de los hombres, a costa de su propia exclusión, y abyecta cuando deviene, como en el ejercicio de las dictaduras más feroces, la expresión soberana de una fría destrucción de todo vínculo genealógico (13-4).

Dos títulos oximorónicos sugieren lo anterior: "El atroz [abyecto] redentor [sublime] Lazarus Morell”, "El incivil [abyecto] maestro de ceremonias [sublime] Kotsuké no Suké" 12 . En estos, así como en los demás infames, lo sublime consiste, sugerimos, en la leyenda, en una especie de aura heroica que se teje alrededor de los infames. Borges lo afirma directamente en dos ocasiones: refiriéndose irónicamente a la leyenda de Billy the Kid: "Nunca se pareció del todo a su leyenda, pero se fue acercando" (66) y: "Es verosímil suponer que Morell se negó a la placa bruñida; esencialmente para no dejar inútiles rastros, de paso para alimentar su misterio...” (21).

Foucault, a su manera, percibe el resplandor que alimenta las leyendas y los mitos de los infames:

Hablo de "leyenda", porque aquí se produce como en todas las leyendas un cierto equívoco entre lo ficticio y lo real, aunque en este caso las razones se invierten. [...] Es algo indiferente a la existencia o inexistencia de aquel a quien transmite la gloria. Si el héroe existió la leyenda lo recubre con tantos prodigios, lo enriquece de tantos atributos imposibles que es, o casi es, como si no hubiese vivido (182-3).

El siguiente fragmento de Roudinesco refleja, asimismo, la dinámica de los infames: "Absoluto del bien o locura del mal, vicio o virtud, condena o salvación: tal es el universo cerrado por el que el perverso circula con deleite, fascinado por la idea de poder liberarse del tiempo y de la muerte" (14). Más que otra cosa, la embriagadora seducción de poder hace que se liberen momentáneamente del tiempo y de la muerte. Proponemos que la vía hacia la sublimación pasa a través de la abyección; es, como se ha indicado en la introducción, la acumulación de actos abyectos lo que hace que dejen la esfera de la abyección para habitar en la de la sublimación y la leyenda. Según la autora de Nuestro lado oscuro, "la alternancia de sublime y abyecto [...] caracteriza nuestro lado oscuro en su aspecto más herético, pero también más luminoso: una servidumbre voluntaria concebida como la expresión de la suprema libertad" (19). Es decir, el ser incluidos en

12 Gallo encuentra que HUI utiliza epítetos en los títulos a semejanza de lo que se acostumbra en los héroes épicos: "El discurso narrativo de HUI a menudo nombra a los personajes usando un recurso que los equipara a los héroes épicos: el epíteto, parecido en su uso clásico y función a los alias y apodos de los malhechores modernos. [...] en HUI, 'Billy the Kid' para Bill Harrigan, o 'Tom Castro el impostor inverosímil', o 'Lazarus Morell el atroz redentor', etc. Todos estos modos de nombrar marcan la prioridad de un rasgo que convierte al personaje en estereotipo. En el héroe épico este recurso estiliza y subraya el perfil del personaje, en una síntesis de lo que es considerado esencial. En los héroes de HUI esa estilización operada por el epíteto, que se combina ahora con la dispersión de nombres y la usurpación de identidad, contribuye a un efecto contrario: la disminución del ser. [...] el epíteto usado a su vez en HUI nombra al personaje reduciéndolo a un rasgo pero en lugar de hacer resaltar el perfil del héroe estilizándolo como en la epopeya, este recurso sirve en HUI para contribuir a desvanecerlo" (96-7). 
la HUI garantiza el sitio en la cumbre de la infamia, lo que lleva a la sublimación: "Son ellos los hombres de leyenda gloriosa pese a que las razones de su fama se contrapongan a las que hicieron o deberían hacer la grandeza de los hombres. Su infamia no es sino una modalidad de la universal fama" (Foucault 185). Esta vacilación en la caracterización o, más bien, la transformación en cuanto a la recepción lectora del personaje, se vincula con la siguiente idea de Valderrama: "A la estricta disposición de degradación para el personaje se añade una intencionada destrucción del pacto tradicional con las funciones del héroe y el malvado. Ambas acciones provocan la inclusión forzosa de contratextos retroactivos" (122). Otra manera de aproximarse a dicha dicotomía y alternancia es considerando los valores universales en comparación con los que rigen cierta comunidad. Valderrama, analizando el fenómeno de los infames en la obra de Borges, y refiriéndose específicamente a los cuentos "El indigno" y "Hombre de la esquina rosada", comenta que "el compadre asesino de Francisco Real" es "noble desde la perspectiva de ese relato y desde la de todos los habitantes del pueblo; al asesinar, creía estar defendiendo su honor y el de los suyos" (97). En otras palabras, tal como refleja el fragmento ya citado de Foucault, tanto en el caso del asesino de Francisco Real, como en el de los personajes examinados de HUI se reflejan otros valores de su comunidad, como el honor de sus miembros, y estos no corresponden necesariamente a los valores universales de no matar, no engañar, no robar, etcétera. De este modo, su infamia pierde la connotación reprochable y se convierte en fama.

Lazarus Morell, ya en el ocaso de su poder, sigue deseando la transcendencia: "Morell, despeñado y casi deshecho por la traición, meditaba una respuesta continental: una respuesta donde lo criminal se exaltaba hasta la redención y la historia" (27). Otros infames cumplen el itinerario para ser reunidos en el libro de una muestra universal de la infamia. Bogle, por su ingenio en la manipulación de las emociones maternas y la avaricia humana - "Orton contaba con el apoyo de los innumerables acreedores que habían determinado que él era Tichborne, para que pudiera pagarles" (38)-; la viuda Ching, por su condición inverosímil de ser una mujer con un poder extraordinario, controlando un gran territorio marítimo y teniendo bajo su mando una armada integrada por "seis escuadrillas" (44); Monk Eastman (denominado "héroe" por el autor), ante el cual Al Capone resulta "epiceno y fofo" (55), también es objeto de leyendas que se traman: "La leyenda refiere que el empresario no lo quiso atender y que Monk demostró su capacidad demoliendo con fragor el par de gigantes que detentaban el empleo. Lo ejerció hasta 1899, temido y solo" (55); Billy the Kid, por su juventud y lo que logró en su corta vida: "El casi niño que al morir a los veintiún años debía a la justicia de los hombres veintiuna muertes - «sin contar mejicanos»" (61); Kotsuké no Suké, por despertar "preciosas lealtades y [ser] la negra y necesaria ocasión de una empresa inmortal" (69); por último, Hákim logra sublimación por una impostura formidable al manipular los sentimientos religiosos de un gran número de fieles (a diferencia de Tom Castro y Bogle quienes se aprovecharon de una familia), declarándose el profeta de dios. 
Cabe destacar que los hechos clave a que se deben los infames no se enuncian explícitamente como "malos"; esto se desprende de un conjunto de valores del bien y del mal supuestos por el lector. Oscar Montanaro Meza afirma que:

Importa destacar cómo en el relato «La viuda Ching, pirata» el narrador no contrapone los conceptos antagónicos de Bien y Mal, Vida y Muerte, Realidad y Ficción, Civilización, Barbarie, sino que los integra dentro de la diégesis. De ello se desprende la ausencia de actitudes maniqueas en el relato analizado, así como en otros relatos que integran este libro (80).

La sublimación consiste únicamente en el exceso de infamia, que los levanta a ser selectos para una historia universal, sin que sea implícito algún hecho que los aproxime a los valores del bien.

\section{Rumbo a una conclusión: el goce del poder}

En las reflexiones sobre la infamia y los infames hemos visto que la infamia se plasma temporal y espacialmente, lo mismo que los héroes-antihéroes que la llevan a cabo; para que logren acceder al poder, ya sea dentro o fuera de la ley, es imperativo que ejecuten un conjunto de reglas de conducta restringiendo libertades, es decir, realizando hechos infames. Los infames seleccionados en HUI merecen este distintivo ya que, aunque sea por un periodo corto, imponen sus reglas del juego. Los infames de Borges no experimentan lo que Roudinesco denomina "el goce del mal"; más bien, ellos gozan del poder, mientras que el mal, sus actos, son el medio para escalar y conquistar la cumbre del poder. Una vez conquistada, los infames adquieren propiedades semidemiúrgicas con las leyendas y mitos que emergen en torno a ellos. Así ascienden a la sublimación, aspecto que los ubica en una universalidad ${ }^{13}$. Todos - los infames y los que están en el poder-, de una manera u otra, emplean el arma de la palabra para fundamentarse; en HUI algunos acuden a la violencia o tortura física, ya sea para comprobar la "veracidad" de sus palabras (Hákim de Merv, Lazarus Morell) o para aplicarlas como alternativa de las palabras (Billy the Kid, Monk Eastman), pero transgreden normas o valores. Foucault asegura que esta transgresión hace de los infames, los otros, algo necesario para que el poder en turno logre consolidarse. La infamia estalla, podría aseverarse entonces, por esa tensión entre la abyección y la sublimación, a través de circunstancias de un espacio y tiempo específicos que logran proyectar universalmente a un infame que trasciende mediante ciertos actos y se proyecta universalmente. El goce del poder, de infames y no tanto, se nos hace

13 Sin emplear el término de universalidad, Valderrama identifica el dinamismo de la supresión de la identidad individual: "La identidad de estos personajes termina siempre anulada, sea a través de una violenta inversión final o mediante una serie de auto-justificaciones con las que, irónicamente, se pone en duda la perspectiva del contexto cultural de ese infame y, más allá, del mundo fuera de esa ficción” (121). 
presente con un encumbrado Borges que se vale también de algunos infames universales, al menos en el multicitado libro, para sublimarse una vez más, empoderarse a través de su palabra.

\section{Referencias}

Barros-Lémez, Álvaro. "Las infamias de Borges. Apuntes para otra historia posible”. Letras-Uruguay. 1986: s.p. Web. 20 Jun. 2014.

Borges, Jorge Luis. Historia universal de la infamia. Madrid: Alianza, 2008. Impreso. Diccionario de la Real Academia Española, s.p. Web. 5 Oct. 2015.

Foucault, Michel. La vida de los hombres infames. Madrid: Las ediciones de la Piqueta, 1990. Impreso.

Gallo, Marta. "Historia universal de la infamia: una lectura en clave épica”. Variaciones Borges 11 (2001): 81-101. Impreso.

Juárez, Laura. "Historias criminales y ficciones infames. El delito en la producción periodística final de Roberto Arlt". Anales de Literatura Hispanoamericana 38 (2009): 321-340. Impreso.

Molloy, Sylvia. Las letras de Borges. Buenos Aires: Sudamericana, 1979. Impreso.

Montanaro Meza, Oscar. "Historia universal de la infamia: Subversión del discurso narrativo de Borges". Sociocriticism 15 (1992): 59-82. Impreso.

Morino, Angelo. [Prefacio]. Yo, Pierre Rivière, habiendo degollado a mi madre, mi hermana y mi hermano... Pierre Rivière. Presentación de Michael Foucault. Barcelona: Tusquets, 1976. I-v. Impreso.

Olea Franco, Rafael. El otro Borges. El primer Borges. México DF/Buenos Aires: El Colegio de México/Fondo de Cultura Económica, 1993. Impreso.

Rivkin, Julie y Michael Ryan, eds. "Strangers to Ourselves: Psychoanalysis". Literary Theory: an Anthology. Malden/Oxford/Carlton: Blackwell Publishing, 2004. 389-396. Impreso.

Roudinesco, Élisabeth. Nuestro lado oscuro. Barcelona: Anagrama, 2009. Impreso.

Valderrama Botana, Marta. "Los personajes infames en la narrativa breve de Jorge Luis Borges”. Moenia 14 (2008): 93-124. Impreso.

Vrhel, František. "Leyendo Historia universal de la infamia". Ibero-Americana Pragensia 23 (1989): 21-28. Impreso.

Recibido: 25 junio 2014 Aceptado: 13 septiembre 2015 